\title{
Faktor Risiko Kematian Neonatal Dini di Rumah Sakit Bersalin
}

\section{Risk Factor of Early Neonatal Mortality in the Maternity Hospital}

\author{
Andi Zulkifli Abdullah* M. Furqaan Naiem** Nurul Ulmy Mahmud*
}

\begin{abstract}
*Bagian Epidemiologi Fakultas Kesehatan Masyarakat Universitas Hasanuddin, **Bagian Kesehatan dan Keselamatan Kerja Fakultas
\end{abstract} Kesehatan Masyarakat Universitas Hasanuddin

\begin{abstract}
Abstrak
Angka kematian bayi di Indonesia masih tergolong tinggi, kematian neonatal 50\% terjadi pada bayi berat lahir rendah (BBLR) dan lebih dari 50\% kematian bayi adalah kematian neonatal dini. Penelitian ini bertujuan untuk mengetahui faktor-faktor antenatal care (ANC), status imunisasi Tetanus Toxoid (TT) ibu hamil, anemia pada saat hamil, berat lahir, status paritas, dan status hipotermia terhadap kematian neonatal dini. Penelitian menggunakan desain penelitian case control di Rumah Sakit Bersalin Kota Makassar dengan sampel 40 kasus dan 120 kontrol. Data diperoleh melalui wawancara langsung dengan responden. Hasil penelitian menunjukkan bahwa faktor risiko kejadian kematian neonatal dini meliputi ANC (nilai $p=$ 0,000; odds ratio, $\mathrm{OR}=7,333 ; \mathrm{Cl} 95 \%=2,966-18,129$ ), status imunisasi TT (nilai $p=0,000 ; O R=19,205 ; \mathrm{Cl} 95 \%=7,902-46,678$ ), anemia ibu hamil (nilai $p=0,000 ; O R=32,818 ; \mathrm{Cl} 95 \%=7,549-142,674$ ), berat lahir (nilai $p=0,000 ; O R=122,212 ; \mathrm{Cl} 95 \%=32,324-462,068$ ), status paritas (nilai $p=0,000 ; O R=5,537 ; \mathrm{Cl} 95 \%=2,029-15,111$ ), status asfiksia (nilai $p=0,000 ; O R=8,197 ; \mathrm{Cl} 95 \%=0,452-2,745)$. Status hipotermia bukan merupakan faktor risiko kematian neonatal dini (nilai $p=0,815$; OR $=1,114 ; \mathrm{Cl} 95 \%=3,646-18,428)$. Hasil uji regresi logistik ganda menemukan bahwa berat lahir bayi merupakan faktor yang paling berisiko terhadap kematian neonatal dini (nilai $p=0,000$ ).

Kata kunci: Faktor risiko kematian, neonatal dini, angka kematian bayi, bayi berat lahir rendah
\end{abstract}

\section{Abstract}

Infant mortality rate in Indonesia is still high. Fifty percent of the neonatal mortality occurred among low birth weight infants (LBWI) and neonatal mortality within 7 days of life accounted for $50 \%$ of total infant mortalities. This study was aimed to examine the extent of early neonatal mortality risk by antenatal care (ANC), Tetanus Toxoid (TT) immunization status of pregnant women, anemia during pregnancy, birth weight of neonatal, parity status, and hypothermia status. This study was a case control study with direct in- terview to respondents, conducted in the Maternity Hospital of Makassar with 40 cases and 120 controls. Samples were selected by purposive sampling. Study results indicated that risk factor of early neonatal mortality were ANC ( $p$ value $=0,000$; odds ratio, $\mathrm{OR}=7,33 ; \mathrm{Cl} 95 \%=2,966-18,129)$, TT immunization status ( $p$ value $=0,000 ; \mathrm{OR}=19,205 ; \mathrm{Cl} 95 \%=7,902-$ 46,678 ), pregnancy anemia ( $\mathrm{p}$ value $=0,000 ; \mathrm{OR}=32,818 ; \mathrm{Cl} 95 \%=7,549$ $-142,674$ ), birth weight ( $p$ value $=0,000 ; O R=122,212 ; \mathrm{Cl} 95 \%=32,324$ $-462,068$ ), parity status ( $p$ value $=0,000 ; \mathrm{OR}=5,537 ; \mathrm{Cl} 95 \%=2,029$ 15,111 ), asphyxia status ( $\mathrm{p}$ value $=0,000 ; \mathrm{OR}=8,197 ; \mathrm{Cl} 95 \%=0,452-$ 2,745 ), whereas hypothermia status ( $p$ value $=0,815$; OR $=1,114 ; 0,452$ $2,745)$ was not a risk factor. Results of logistic regression multivariate analysis indicated that infant's birth weight was the most risk factor of early neonatal mortality ( $p$ value $=0,000$ ). Specific surveillance program for high risk neonatal needed to be arranged in all health centers.

Key words: Mortality risk factor, early neonatal, infant mortality rate, low birth weight infants

\section{Pendahuluan}

Neonatal adalah bayi yang baru mengalami proses kelahiran dan harus menyesuaikan diri dari kehidupan intrauterine ke kehidupan ekstrauterine. Kematian neonatal dini merupakan kejadian kematian bayi yang berumur 0 sampai $<7$ hari. Kematian bayi di seluruh dunia diperkirakan 11 juta setiap tahun, 60\% kematian bayi terjadi pada masa neonatal dan $40 \%$ kematian neonatal terjadi pada umur satu minggu pertama kehidupan.

Angka kematian bayi di Indonesia masih tergolong tinggi dibandingkan negara Association of Southeast

Alamat Korespondensi: Andi Zulkifli Abdullah, Bagian Epidemiologi FKM Universitas Hasanuddin, Jl. Perintis Kemerdekaan Km. 10 Tamalanrea Makassar 90245, Hp.081342706750,e-mail: zulkifliabdullah@yahoo.com 
Asia Nations (ASEAN) yang lain. Tahun 2003, angka kematian bayi di Indonesia adalah 35 per 1.000 kelahiran hidup dan angka kematian neonatal adalah 25 per 1.000 kelahiran hidup. Lima puluh persen dari kematian neonatal terjadi pada bayi berat lahir rendah (BBLR). Kematian bayi baru lahir sampai umur 7 hari lebih merupakan $50 \%$ dari kematian bayi. BBLR pre term berisiko kematian neonatal dini 52,1 kali lebih besar dan BBLR term mempunyai risiko kematian 4,2 kali dibandingkan bayi berat badan normal. ${ }^{1}$

Berdasarkan hasil Survei Demografi Kesehatan Indonesia (SDKI) tahun 2007 di Indonesia, angka kematian bayi adalah 34 per 1.000 kelahiran hidup, angka kematian neonatal adalah 19 per 1.000 kelahiran hidup, dan kematian neonatal dini adalah 15 per 1.000 kelahiran hidup. Hal ini menunjukkan bahwa angka kematian bayi dan angka kematian neonatal masih lebih tinggi dibandingkan target Millenium Development Goals (MDGs). ${ }^{2}$

Penyebab utama kematian bayi pada minggu pertama kehidupan adalah komplikasi kehamilan dan persalinan seperti asfiksia, sepsis, dan komplikasi berat lahir rendah. Asfiksia neonatorum merupakan keadaan bayi baru lahir gagal bernapas spontan dan teratur segera setelah lahir. Penyebabnya adalah hipoksia janin dalam rahim yang berhubungan dengan berbagai faktor selama kehamilan, persalinan, dan segera setelah lahir. Status gizi ibu sebelum dan selama hamil dapat memengaruhi pertumbuhan janin yang sedang dikandung. ${ }^{3}$ Penelitian ini bertujuan untuk mengetahui faktor-faktor antenatal care (ANC), status imunisasi Tetanus Toxoid (TT) ibu hamil, anemia pada saat hamil, berat lahir, status paritas, dan status hipotermia terhadap kematian neonatal dini di rumah sakit bersalin di Kota Makassar.

\section{Metode}

Penelitian observasional dengan rancangan case control mengamati pengaruh faktor risiko secara retrospektif. Kasus adalah bayi neonatal yang mengalami kematian neonatal dini dan kontrol adalah bayi neonatal yang tidak mengalami kematian neonatal dini, keduanya dipilih dalam kurun waktu yang sama. Lokasi penelitian adalah rumah sakit bersalin di Kota Makassar meliputi Rumah Sakit Ibu dan Anak (RSIA) Siti Fatimah, RSIA Pertiwi, RSIA Siti Khadijah I dan IV, Rumah Sakit Bersalin (RSB) Ananda, dan RSIA Catherine Booth pada periode bulan Maret - Mei tahun 2009. Populasi dalam penelitian adalah seluruh bayi neonatal yang lahir hidup di rumah sakit bersalin Kota Makassar. Populasi target adalah bayi yang lahir hidup sebelum mencapai umur 7 hari di rumah sakit bersalin di Kota Makassar. Matching dilakukan berdasarkan jenis kelamin sama yang tercatat di rekam medis rumah sakit bersalin di Kota Makassar. Sumber data yang digunakan meliputi data sekunder dan data primer. Data primer adalah data variabel penelitian yang tidak tercatat pada data sekunder sehingga diperoleh melalui wawancara terhadap sampel yang terpilih dengan menggunakan kuesioner. Data sekunder adalah data yang diperoleh dari register pasien yang tercatat pada rekam medik rumah sakit bersalin di Kota Makassar.

Analisis data yang dilakukan meliputi analisis bivariat dan multivariat. Analisis bivariat untuk membandingkan distribusi berbagai variabel independen yang diamati pada kelompok kasus dan kontrol serta seleksi variabel kandidat model multivariat dengan kriteria nilai $\mathrm{p}<=$ 0,20 . Penelitian ini juga melakukan kontrol kualitas yang meliputi standardisasi petugas lapangan, standardisasi alat ukur, pengawasan validitas, dan pengawasan reliabilitas.

\section{Hasil}

Penelitian ini didapatkan 160 responden yang terdiri 40 kasus dan 120 kontrol (1: 3). Distribusi setiap variabel independen pada kelompok kasus dan kontrol menunjukkan hanya variabel jenis kelamin yang memperlihatkan distribusi yang sama pada kelompok kasus dan kontrol, laki-laki $=37,5 \%$ dan perempuan $=62,5 \%$. Variabel yang lain berpotensi untuk menjadi faktor risiko (Tabel 1).

Variabel independen yang memenuhi kriteria kandidat model multivariat (nilai $\mathrm{p}<=0,25$ ) adalah $\mathrm{ANC}$, imunisasi TT ibu, anemia ibu hamil, berat badan lahir, paritas, dan status asfiksia (Tabel 2).

Berdasarkan uji analisis secara multivariat menggunakan regresi logistik untuk 6 variabel terlihat bahwa variabel yang paling berpengaruh terhadap kejadian kematian neonatal dini di rumah sakit bersalin Kota Makassar adalah berat lahir (odds ratio, OR $=813,382$ ), sementara untuk variabel lain menunjukkan adanya perubahan, baik pada OR maupun tingkat signifikan (Tabel 3).

\section{Pembahasan}

Pemeriksaan ANC dilakukan untuk mengetahui kesehatan ibu hamil dan perkembangan bayi yang dikandung sehingga diharapkan dapat mencapai kesehatan yang optimal untuk menghadapi masa persalinan, masa nifas, dan laktasi. Ibu hamil diharapkan mempunyai pengetahuan yang memadai tentang pemeliharaan bayinya. ${ }^{4}$ Pemeriksaan ANC yang dianjurkan adalah minimal 4 kali dalam masa kehamilan meliputi minimal 1 kali pada trimester pertama, minimal 1 kali pada trimester kedua, dan minimal 2 kali mada trimester ketiga. Diharapkan setelah pelayanan ANC sesuai standar terpenuhi, selama kehamilan, persalinan, dan nifas ibu tetap sehat, bayi yang dilahirkan sehat kemudian dapat menurunkan morbiditas dan mortalitas maternal dan perinatal. Pada penelitian ini, ibu hamil yang memeriksakan kehamilan kurang dari 4 kali berisiko mengalami kematian neonatal 
Tabel 1. Hasil Analisis Univariat Variabel Penelitian

\begin{tabular}{|c|c|c|c|c|c|}
\hline \multirow{2}{*}{ Variabel } & \multirow{2}{*}{ Kategori } & \multicolumn{2}{|c|}{ Kasus } & \multicolumn{2}{|c|}{ Kontrol } \\
\hline & & $\mathbf{n}$ & $\%$ & $\mathbf{n}$ & $\%$ \\
\hline \multirow[t]{2}{*}{ Jenis kelamin } & Laki-laki & 15 & 37,5 & 45 & 37,5 \\
\hline & Perempuan & 25 & 62,5 & 75 & 62,5 \\
\hline \multirow[t]{2}{*}{ ANC ibu hamil } & $<4$ kali & 16 & 40,0 & 10 & 8,3 \\
\hline & $\geq 4$ kali & 24 & 60,0 & 110 & 91,7 \\
\hline \multirow[t]{4}{*}{ Imunisasi TT ibu hamil } & Tidak pernah & 2 & 5,0 & 2 & 1,7 \\
\hline & Satu kali & 11 & 27,5 & 2 & 1,7 \\
\hline & Dua kali & 15 & 37,5 & 9 & 7,5 \\
\hline & $>$ Dua kali & 12 & 30,0 & 107 & 89,2 \\
\hline \multirow[t]{3}{*}{ Anemia ibu hamil } & Tidak anemia & 4 & 10,0 & 83 & 69,2 \\
\hline & Anemia ringan & 36 & 90,0 & 34 & 28,3 \\
\hline & Anemia sedang & 0 & 0 & 3 & 2,5 \\
\hline \multirow[t]{2}{*}{ Berat badan lahir } & $\leq 2500$ gram & 37 & 92,5 & 11 & 9,2 \\
\hline & $>2500$ gram & 3 & 7,5 & 109 & 90,8 \\
\hline \multirow[t]{4}{*}{ Status paritas } & 1 kali & 33 & 82,5 & 48 & 40,0 \\
\hline & 2 kali & 3 & 7,5 & 44 & 36,7 \\
\hline & 3 kali & 2 & 5,0 & 20 & 16,7 \\
\hline & $\geq 4$ kali & 2 & 5,0 & 8 & 6,6 \\
\hline \multirow[t]{2}{*}{ Status hipotermia } & Ya & 8 & 20,0 & 22 & 18,3 \\
\hline & Tidak & 32 & 80,0 & 98 & 81,7 \\
\hline \multirow[t]{2}{*}{ Status asfiksia } & Ya & 23 & 57,5 & 17 & 14,2 \\
\hline & Tidak & 17 & 42,5 & 103 & 85,8 \\
\hline
\end{tabular}

7,3 kali lebih besar dibandingkan ibu hamil yang memeriksakan kehamilannya lebih dari 4 kali. Penelitian lain di Kabupaten Banyumas menemukan bahwa bayi yang lahir dari ibu yang mendapatkan pelayanan ANC tidak memadai berisiko mengalami kematian perinatal 5,6 kali lebih besar dibandingkan ibu yang mendapatkan pelayanan ANC yang memadai. ${ }^{5}$ Di Nepal, meskipun dua pertiga kasus kematian perinatal memperoleh pelayanan ANC, tetapi hanya seperlima yang melakukan pemeriksaan ANC seperti yang direkomendasikan oleh World Health Organization (WHO). ${ }^{6}$

Penyebab kematian ibu terdiri atas beberapa faktor antara lain perdarahan, infeksi jalan lahir, keracunan kehamilan serta faktor lainnya seperti pelayanan kesehatan ibu hamil, pertolongan persalinan oleh tenaga kesehatan, kondisi sosial ekonomi serta keterampilan petugas kesehatan terutama bidan desa. Akan tetapi, infeksi merupakan penyebab utama kematian dan kesakitan pada neonatal antara lain tetanus neonatorum. Imunisasi TT diharapkan dapat menekan angka infeksi tersebut agar bayi yang dilahirkan sehat. Ibu hamil dengan riwayat imunisasi TT $<2$ kali berisiko 19,2 kali lebih besar untuk mengalami kematian neonatal dini pada bayi yang dilahirkan dibandingkan ibu hamil dengan riwayat imunisai TT $\geq 2$ kali dan secara statistik berhubungan bermakna. Hal ini sesuai dengan penelitian Yunus, ${ }^{7}$ bahwa imunisasi TT ibu hamil dengan nilai OR $=2,5(1,101<$ OR $<5,880)$ merupakan faktor risiko terhadap kejadian kematian neonatal dan berpengaruh terhadap kejadian ke- matian neonatal.

BBLR berkontribusi terhadap kematian bayi pada masa perinatal. Selain itu, BBLR dapat mengalami gangguan mental dan fisik pada usia tumbuh kembang selanjutnya. Anemia pada kehamilan berhubungan signifikan dengan kejadian BBLR. Pada penelitian ini, ibu hamil dengan riwayat anemia berisiko 32,8 kali lebih besar untuk mengalami kematian neonatal dibandingkan ibu hamil tanpa riwayat anemia. Penelitian di Nepal dengan studi restrospektif pada 816 persalinan periode bulan April 2007 - Maret 2008 pada 76,5\% kematian perinatal dan $100 \%$ kematian neonatal dini adalah bayi dengan berat lahir rendah. 8 Menurut WHO, wanita hamil yang menderita anemia dengan kadar hemoglobin $(\mathrm{Hb})$ kurang dari 11 gram \% terjadi perubahan sirkulasi darah karena tambahan suplai ke plasenta dan pembesaran organ seperti uterus dan payudara. Selain itu, terjadi perubahan hematologi berupa plasma darah dan sel darah merah yang meningkat dengan perbandingan plasma darah $30 \%$, sel darah merah $18 \%$, dan $\mathrm{Hb} 19 \%$.

Pada kehamilan terjadi peningkatan kebutuhan zat besi. Kebutuhan zat besi selama 40 minggu kehamilan adalah $750 \mathrm{mg}$ yang meliputi $425 \mathrm{mg}$ untuk ibu hamil, $300 \mathrm{mg}$ untuk janin, dan $25 \mathrm{mg}$ untuk plasenta. ${ }^{9} \mathrm{Hal}$ ini menunjukkan pentingnya zat besi selama kehamilan. Proses hemodilusi tersebut akan menjadi hal patologis bila asupan zat gizi kurang dan malabsorpsi. Asupan gizi yang kurang dan malabsorpsi akan menyebabkan keti- 
Tabel 2. Hasil Analisis Bivariat untuk Seleksi Variabel Kandidat Model Multivariat

\begin{tabular}{llll}
\hline Variabel & OR & Nilai $\mathbf{p}$ & Diikutkan \\
\hline ANC & 7,3 & 0,000 & Ya \\
Imunisasi TT ibu & 19,2 & 0,000 & Ya \\
Anemia ibu hamil & 32,8 & 0,000 & Ya \\
Berat badan lahir & 122,2 & 0,000 & Ya \\
Status paritas & 5,5 & 0,000 & Ya \\
Status hipotermia & 1,1 & 0,815 & Tidak \\
Status asfiksia & 8,19 & 0,000 & Ya \\
\end{tabular}

Tabel 3. Analisis Multivariat dengan Regresi Logistik Variabel Penelitian

\begin{tabular}{|c|c|c|c|c|c|}
\hline \multirow{2}{*}{ Variabel } & \multirow{2}{*}{ B } & \multirow{2}{*}{ Sig. } & \multicolumn{2}{|c|}{$\operatorname{Exp}(B)$} & \multirow{2}{*}{$\mathbf{9 5 , 0} \%$ CI for $\operatorname{Exp}(\mathbf{B})$} \\
\hline & & & Lower & Upper & \\
\hline ANC & 0,748 & 0,650 & 2,1 & 0,08 & 53,25 \\
\hline Imunisasi TT & 3,326 & 0,012 & 27,8 & 2,08 & 371,89 \\
\hline Anemia ibu hamil & 4,997 & 0,001 & 148,0 & 7,44 & 2945,58 \\
\hline Berat lahir & 6,701 & 0,000 & 813,4 & 22,82 & 28996,37 \\
\hline Status paritas & 3,898 & 0,032 & 49,3 & 1,40 & 1733,58 \\
\hline Status asfiksia & 3,899 & 0,022 & 49,3 & 1,76 & 1387,03 \\
\hline Constant & $-33,634$ & 0,001 & 0,0 & & \\
\hline
\end{tabular}

dakseimbangan sehingga berdampak pada penurunan $\mathrm{Hb}$ darah. Apabila asupan gizi cukup dan tidak terjadi malabsorpsi tetapi terjadi perdarahan atau penyakit kronis maka akan terjadi penurunan $\mathrm{Hb}$ yang mempersulit kehamilan.

Asfiksia adalah salah satu penyebab utama kejadian kematian neonatal dini maka status BBLR memiliki pengaruh terhadap kejadian kematian neonatal dini. Kehamilan menyebabkan peningkatan metabolisme energi. Oleh karena itu, kebutuhan energi dan zat gizi lain meningkat selama kehamilan. Peningkatan energi dan zat gizi tersebut diperlukan untuk pertumbuhan dan perkembangan janin, pertambahan besarnya organ kandungan, serta perubahan komposisi dan metabolisme tubuh ibu sehingga kekurangan zat gizi tertentu yang diperlukan saat hamil dapat menyebabkan janin tumbuh tidak sempurna. Ibu hamil dengan riwayat status gizi risiko tinggi berisiko 122,2 kali lebih besar mengalami kematian neonatal dibandingkan ibu hamil dengan riwayat status gizi risiko rendah dan secara statistik bermakna. Penelitian prospektif di Bangladesh pada 770 kelahiran cukup bulan menemukan kejadian asfiksia lahir pada neonatal yang BBLR adalah 10,0\% sedangkan pada neonatal dengan berat lahir normal adalah 1,4\%. Perbedaan kejadian asfiksia lahir pada neonatal BBLR dengan neonatal berat lahir normal bernilai signifikan secara statistik (nilai $\mathrm{p}<0,000$ ). ${ }^{10}$

Kebutuhan energi pada trimester pertama meningkat secara minimal. Kemudian sepanjang trimester kedua hingga ketiga kebutuhan energi terus meningkat sampai akhir kehamilan. Energi tambahan selama trimester kedua diperlukan untuk pemekaran jaringan ibu seperti penambahan volume darah, pertumbuhan uterus, dan payudara serta penumpukan lemak. Selama trimester ketiga energi tambahan digunakan untuk pertumbuhan janin dan plasenta. Bahan pangan yang dijadikan sumber protein sebaiknya 2 per 3 bagian pangan yang bernilai biologi tinggi seperti daging tak berlemak, ikan, telur, susu, dan hasil olahan lainnya. Protein yang berasal dari tumbuhan karena nilai biologinya rendah cukup sepertiga bagian saja.

Primipara adalah keadaan ibu telah melahirkan seorang bayi viabel, multipara jika ibu telah beberapa kali melahirkan bayi hidup, dan grandemultipara adalah ibu yang telah melahirkan 5 anak atau lebih dan biasanya mengalami penyulit dalam kehamilan dan persalinan. ${ }^{11}$ Ibu hamil yang melahirkan bayi pertama dan $\geq 3$ kali berpeluang 5,5 kali untuk mengalami kematian neonatal dibandingkan ibu yang melahirkan 2 kali dan secara statistik bermakna. Seorang ibu dengan interval yang pendek antara 2 kehamilannya mempertinggi risiko terjadinya komplikasi seperti kelahiran prematur dan keguguran. Selain itu, seorang ibu yang mempunyai jarak kehamilan kurang dari 6 bulan akan mengalami banyak komplikasi daripada ibu dengan jeda kehamilan lebih lama. Beberapa penelitian mendapatkan hasil bahwa ke- 
jadian BBLR lebih banyak terjadi pada ibu melahirkan dengan paritas tinggi. Paritas adalah banyaknya kelahiran hidup yang dipunyai seorang wanita. ${ }^{12}$ Paritas terdiri atas primipara, multipara, dan grandemultipara.

Bayi baru lahir yang mudah mengalami hipotermia dapat menyebabkan penurunan kadar glukosa tubuh. Keadaan tersebut memungkinkan komplikasi hipotermia seperti infeksi, asfiksia, dan lain-lain. Bayi dengan riwayat hipotermia berisiko 1,1 kali lebih besar untuk mengalami kematian neonatal dini dibandingkan bayi dengan riwayat hipotermia dengan risiko rendah dan analisis dinyatakan tidak ada hubungan yang bermakna $(\mathrm{OR}=1,114 ; 95 \% \mathrm{CI}=0,452<\mathrm{OR}<2,754)$. Hipotermia pada neonatal merupakan salah satu masalah kesehatan terutama pada bayi baru lahir. WHO memperkirakan bahwa 18\% - 42\% dari kematian bayi di seluruh dunia setiap tahunnya disebabkan oleh hipotermia. ${ }^{13}$

Kriteria objektif menentukan asfiksia hanya dengan melihat pernapasan spontan cukup longgar. Meskipun asfiksia memiliki makna dan pengaruh yang cukup kuat, namun pengaruh bias penilaian tersebut juga perlu dipertimbangkan. Di negara berkembang, sekitar 3\% bayi mengalami asfiksia lahir tingkat sedang dan berat. Jumlah bayi asfiksia yang mampu bertahan hidup tetapi mengalami kerusakan otak cukup banyak. Hal ini disebabkan oleh resusitasi tidak dikerjakan atau apabila dikerjakan prosedurnya tidak adekuat atau salah. Resusitasi yang dilaksanakan secara memadai dapat mencegah kematian dan kecacatan pada bayi. Pada penelitian ini, bayi dengan riwayat menderita asfiksia berisiko 8,2 kali lebih besar untuk mengalami kematian neonatal dini dibandingkan bayi dengan riwayat asfiksia dengan risiko rendah dan secara secara statistik bermakna (OR $=8,197 ; 95 \% \mathrm{CI}=3,646<\mathrm{OR}<18,428)$. Menurut WHO, proporsi kematian neonatal akibat asfiksia lahir adalah $21,1 \%$. Proporsi kematian neonatal akibat asfiksia lahir 2 kali lebih besar dari laporan WHO yaitu $43,8 \% .{ }^{14}$ Beberapa penelitian sejenis juga mengungkapkan bahwa asfiksia merupakan salah satu penyebab kematian pada bayi baru lahir. Di Nepal, asfiksia adalah penyebab utama kematian neonatal dini $(33,0 \%)$ diikuti gangguan pernapasan $(25,0 \%)$ dan infeksi $(24,0 \%) .{ }^{6} \mathrm{Di}$ Tanzania, penyebab utama kematian neonatal dini adalah infeksi $(32,0 \%)$, komplikasi kelahiran prematur $(27,0 \%)$, dan asfiksia $(26,0 \%) .{ }^{15}$

\section{Kesimpulan}

Berdasarkan hasil penelitian dapat disimpulkan bahwa faktor risiko kejadian kematian neonatal dini adalah ANC, status imunisasi TT, anemia ibu hamil, berat badan lahir, status paritas, dan status asfiksia sedangkan status hipotermia bukan merupakan faktor risiko kejadian kematian neonatal dini. Berat lahir merupakan faktor yang paling berisiko terhadap kejadian kematian neonatal dini. Rentang nilai lingkar lengan dan ukuran lengan yang cukup lebar mengindikasikan bahwa ada beberapa faktor bias yang dapat memengaruhi hasil penelitian pada setiap variabel.

\section{Saran}

Perlu dilakukan penelitian lebih lanjut dengan metode yang lebih spesifik dengan jumlah sampel yang lebih besar sehingga dapat meminimalkan bias pada hasil penelitian. Selain itu, kegiatan surveilans khusus pada neonatal risiko tinggi di seluruh puskesmas dan rumah sakit bersalin serta asupan nutrisi kepada ibu hamil dapat menjadikan prioritas sebagai upaya mengurangi risiko kematian neonatal dini.

\section{Daftar Pustaka}

1. Suryatni. Faktor risiko kejadian neonatal dini pada bayi BBLR di RSUD Pekanbaru Riau. 2004.

2. Kementerian Kesehatan Republik Indonesia. Pencapaian target MDGs di provinsi binaan direktorat jenderal bina gizi dan KIA (Jawa Tengah, Banten, dan Papua Barat) tahun 2010. Jakarta: Direktorat Jenderal Bina Gizi dan KIA; 2011.

3. Lubis Z. Status gizi ibu hamil serta pengaruhnya terhadap bayi yang dilahirkan. Bogor: Laporan Penelitian Institut Pertanian Bogor; 2003.

4. Lemeshow S. Besar sampel dalam penelitian kesehatan. Yogyakarta: Gajah Mada University Press; 1997.

5. Anwar MC. Hubungan kualitas pemeriksaan antenatal dengan kematian perinatal: studi kasus di Kabupaten Banyumas. Semarang: Institutional Repository Diponegoro University. Diunduh dari: http://www.eprints. undip.ac.id/18374.

6. Manuaba I. Kepaniteraan klinik obstetri dan ginekologi. Edisi kedua. Jakarta: Penerbit Buku Kedokteran EGC; 2004.

7. Puri M, Malla K, Aryal DR, Shrestha M, Hulton L, Pradhan AS. Support to safe motherhood programme Nepal: a part of government of Nepal national safe motherhood programme (NNSMP). Maternal and perinatal death review in Nepal. 2008 January. Available from: http://www.safemotherhood.org.np/pdf/100Maternal\%20and \%20Perinatal\%20Death\%20Review\%20in\%20Nepal.pdf.

8. Yunus M. Faktor risiko kematian neonatal di Kabupaten Konawe Sulawesi Tenggara. Kendari; 2008.

9. Shrestha S, Sharma S, Upadhyay S, Rijal P. Perinatal mortality audit. Nepal Medical College Journal. 2010; 12 (4): 257-9. Available from: http://www.nmcth.edu /images/gallery/Editorial/6fZYfs_shrestha.pdf

10. Widjanarko B. Anemia dalam kehamilan. 2011. Available from: http://www.reproduksiumj.blogspot.com/2011/09/anemia-dalam-kehamilan.html.

11. Bari MI, Ullah MA, Khatun M. Morbidity and mortality of low birth weight baby. The Journal of Teachers Association RMC, Rajshahi. 2008; 21 (1). Available from: http://www.banglajol.info/index.php/TAJ/article/ download/3216/2702.

12. Badan Kependudukan dan Keluarga Berencana Nasional. Deteksi dini komplikasi persalinan. Jakarta: Badan Kependudukan dan Keluarga Berencana Nasional; 2006. 
13. Manuaba. Ilmu kebidanan, kandungan, dan KB. Jakarta: EGC; 2008.

14. World Health Organization. Intervention to prevent hypothermia at birth in preterm and/or low birth weight infants. RHL the WHO Reproductive Health Library. 2010.

15. World Health Organization. Report of working group on anemia.
Geneva: WHO Report; 1992; 17020.

16. United Republic of Tanzania. Situation analysis of newborn health in Tanzania. 2009. Available from: http://www.public.maildirect.se /30/984400ac-d9e4-4f7a-b54d-4f87249280e6/Documents/ TanzaniaSitAn-red.pdf. 